\title{
DCLRE1A wt Allele
}

National Cancer Institute

\section{Source}

National Cancer Institute. DCLRE1A wt Allele. NCI Thesaurus. Code C106143.

Human DCLRE1A wild-type allele is located in the vicinity of 10q25.1 and is approximately $20 \mathrm{~kb}$ in length. This allele, which encodes DNA cross-link repair 1A protein, is involved in both interstrand DNA repair and cell cycle progression. 